The Annals of Statistics

2002, Vol. 30, No. 6, 1535-1575

\title{
JOHN W. TUKEY: HIS LIFE AND PROFESSIONAL CONTRIBUTIONS ${ }^{1}$
}

\author{
BY DAVID R. BRILLINGER \\ University of California, Berkeley
}

\begin{abstract}
As both practicing data analyst and scientific methodologist, John W. Tukey made an immense diversity of contributions to science, government and industry. This article reviews some of the highly varied aspects of his life. Following articles address specific contributions to important areas of statistics.
\end{abstract}

I believe that the whole country-scientifically, industrially, financially-is better off because of him and bears evidence of his influence.

John A. Wheeler, Princeton Professor of Physics Emeritus [65]

1. Introduction. John Wilder Tukey (JWT)—chemist, topologist, educator, consultant, information scientist, researcher, statistician, data analyst, executivedied of a heart attack on July 26, 2000 in New Brunswick, New Jersey. The death followed a short illness.

Tukey was born in New Bedford, Massachusets on June 16, 1915. He was educated at home until commencing college. He obtained B.Sc. and M.Sc. degrees in chemistry from Brown University and then he went to graduate school at Princeton. At Princeton he obtained M.A. and Ph.D. degrees in mathematics. In 1985 at age 70 he retired from Bell Telephone Laboratories and from teaching at Princeton University with a "Sunset salvo" [97].

While JWT's graduate work was mainly in pure mathematics, the advent of World War II led him to focus on practical problems facing his nation and thereafter to revolutionize methods for the analysis of data. This encompasses most everything nowadays. At the end of the War he began a joint industrialacademic career at Bell Telephone Laboratories, Murray Hill and at Princeton University. Science and the analysis of data were ubiquitous. Even after retirement his technical and scientific work continued at a high level of creativity.

An avowed scientific generalist, JWT made a remarkable number of contributions to science, academia and industry and to his nation during a more than sixtyyear career. His immense productivity and diversity defy ready summary. This

Received September 2001; revised April 2002.

${ }^{1}$ Supported by NSF Grants DMS-97-04739 and DMS-99-71309.

AMS 2000 subject classifications. 01A70, 54-03, 62-03, 68-03.

Key words and phrases. Bell Labs, computational mathematics, computers, cryptography, data analysis, history, information theory, John W. Tukey, mathematics, neologisms, Princeton University, statistics. 
article touches on some aspects of his educational and professional life, perhaps to serve future biographers.

The article traces JWT's career chronologically and then discusses specific areas in which he had substantial impact. The Appendices list: (A) A time line; (B) Some academic honors; (C) Ph.D. students; (D) Some JWT words and phrases; and (E) Some sayings.

Some of Tukey's many contributions to statistical science follow in other articles in this Special Number of the Annals. They discuss important parts of his work in statistical science. The authors and articles are: Braun and Benjamini, "John W. Tukey's contributions to multiple comparisons"; Brillinger, "John W. Tukey's work on time series and spectrum analysis"; Dempster, "John W. Tukey as "philosopher"; Friedman and Stuetzle, "John W. Tukey's work on interactive graphics"; Huber, "John W. Tukey's contributions to robust statistics"; and Speed, "John W. Tukey's contributions to analysis of variance."

There are many John Tukey stories, and a few are related in Section 15. One concerns Peter Huber, who has contributed so much to the field of robust methods. In the early sixties I was in charge of the Statistics seminar at Princeton. One day JWT came to me quite excitedly: "There is another topologist working in statistics! Please invite him to speak." That was my introduction to Peter Huber.

2. The early years. Tukey was the only child of Adah M. Tasker and Ralph H. Tukey. One of his ancestors, another John, came to Portland, Maine from England in 1744. Today there may be found in Maine Tukey's Bridge, Tukey's Road and many Tukeys. His parents left his birthplace, New Bedford, Massachusetts, for a period but returned to settle there when John was 5 .

Tukey was a prodigy. His parents had not realized that he had learned to read until on a driving trip there was concern over whether a particular bridge over the Susquehanna was closed. Aged 3 years, he spoke up to say that the bridge was closed. He had read a legal notice (!) in the newspaper announcing the closure [39].

Tukey received an unconventional education before college: home schooling. His mother was concerned that he would become lazy or a discipline problem at school. Such an education was particularly viable for him because both his parents were teachers at New Bedford High School, and his mother, being married, was not allowed to teach full time. John did have semesters of French, chemistry laboratory and mechanical drawing at the high school. One way in which he particularly distinguished himself was by helping with the school's timetable of classes. He later remarked that by doing this he learned how to show "politely" the teachers how to do certain things [7].

In his studies in New Bedford JWT made substantial use of the Public Library. That library was unusual in including the Transactions of the American Mathematical Society and the Journal of the American Chemical Society. He remarked that he thought he first trained as a chemist because he could read the JACS, but not the Transactions [7]. Concerning his early mathematics education 
JWT noted that he had gotten a lot of calculus out of the way before going on to Brown University [5].

\section{The Brown years.}

Perhaps because I began in a hard but usually non-deductive science-chemistry-and was prepared to learn "facts" rather than "proofs," I have found it easier than most to escape the mathematician's implicit claim that the only real sciences are the deductive ones.

John attended nearby Brown University, entering in 1933. Because of his home education, JWT had to enter by way of the College Board exams [7]. His wife Elizabeth once said that when she told the Personnel Director at the Educational Testing Service that she was about to marry John, he replied of John that, "He got the highest score on the SATs that we have ever seen" [51].

Concerning his college education JWT said: "When I was at Brown I read a very diverse set of books from the math library" [7]. Brown was a good choice, for at that time it probably had the best mathematics library in the country. In his sophomore year JWT was already taking graduate courses in mathematics, in particular from the analysts C. R. Adams and J. Tamarkin [7]. In the spring of 1937 he took a topology course from S. Ulam [5]. John remarked that in those years he had "a little tin case with 3 by 5 cards in it for what seemed to be interesting statistical techniques." In 1936, that is, after 3 years, he obtained an Sc.B. in Chemistry.

John was a Lab Assistant in Physical Chemistry during the period 19351937. In 1937 he obtained an Sc.M. in Chemistry. It is revealing that preparation for that degree involved laboratory experimental work. JWT often spoke of his Brown education in chemistry. He had learned as well "large doses of physics and substantial doses of geology." The importance of this to him shows in many places, such as the articles "The education of a scientific generalist" [15] and "Use of numerical spectrum analysis in geophysics" [84].

Tukey was clearly proud of having gone to Brown and often wore its necktie. After Donald Hornig became President of Brown in 1970, he invited Tukey to join the Brown Corporation (the governing body of the university). Hornig and Tukey had known one another through the President's Science Advisory Committee (PSAC) and other national service activities. Tukey clearly relished this renewed affiliation with Brown, devoting much time not only to the Brown Corporation, but also to helping his alma mater plan for its computer needs, to serving on a Library committee and to participating in decisions with Brown Mathematics Faculty members. Not far from his upbringing in New Bedford and his waterfront home in Westport Point, Massachusetts that he purchased circa 1970, Brown was very much a part of Tukey's home turf.

Tukey's books went to Brown University in the largest such donation that the University received to that point. The 14,000 volumes included scientific and 
technical books; but most of them were his extensive collection of detective, adventure and science fiction stories.

\section{Princeton: The student years.}

It ended in a draw.

A.W. Tucker on a course he taught and JWT attended [75]

JWT went to Princeton University after Brown. His remarks on receiving Princeton's James Madison Medal in 1984 included:

Like those who have stood here in earlier years, I am deeply honored to be here. Unlike them, I cannot talk of returning, for I enjoyed the Princeton Graduate School so much that I have not yet left it.

He said that he had picked Princeton because of its Chemistry Department. He remarked that during the summer of 1937 he "fell over the fence" into Mathematics.

4.1. The Tuke. One has the strong impression that Tukey and his friends had a wonderful time in their graduate years at Princeton. John arrived there in September 1937. The university was then very much a male bastion and remained so until the early 1970s. He lived in the Graduate College for the first two years and again off and on until he married in 1950.

The Graduate College and Fine Hall, where the Mathematics Department was located, were very special places. Tukey's Madison award remarks included:

First there were the pre-war days: academic gowns for dinner, whatever was worn underneath; sad Sunday evening meals when the "Green Pots" appeared; and the lunchtime exchange with a waiter: "chiz or frut?"- "what's the frut?"-_cupcake," that only a Graduate College resident of those times would recognize as referring to mixed fruit, from a can, over a cupcake.

Friends included: mathematicians Ralph Boas, G. W. King, M. Kanner, A. Sonte, astronomer Lyman Spitzer, mathematicians Frank Smithies and Henry Wallman. In later years his group included chemist Bill Baker, G. W. Brown, physicist Richard Feynman, engineer Brockway MacMillan, economist Oskar Morgenstern and mathematician Norman Steenrod. Fred Mosteller noted that "Night after night Feynman and Tukey dazzled all who could crowd around at the graduate school dinner" [60].

Tukey remembered that he had met Baker on a tennis court. It is intriguing that, when JWT was elected to the National Academy of Sciences, his colleagues in Mathematics signed and gave him a tennis ball. (I saw the presentation, but I don't know the details of the story.) He did play a lot of ping pong in the fifties, sixties and seventies.

One graduate school entertainment was a collection of mathematical methods for catching lions! L. Spitzer [73] writes: 
In 1935-1936, when I was a first-year graduate student at St. John's College, Cambridge, the light banter among us included how to catch a lion in the desert; we delighted in devising ingenious methods, preferably based on more recondite scientific laws or theorems.

During my two graduate-student years at Princeton, 1936-1938, this continued to intrigue us. If I recall correctly, it was John Tukey in applied mathematics, who took the major initiative in promoting a publishable paper on this problem. In the end the paper was sent off to the American Mathematical Monthly with a covering letter signed by one E. S. Pondiczery, the name proposed by John as a cover for our group.

The material was written up by R. P. Boas and F. Smithies [71] and appeared in [62]. Part of JWT's assistance was in keeping the nonexistence of the nominal author, H. Pétard and of Pondiczery quiet when the Monthly enquired about the paper's author. The full identification of Pondiczery was Ersatz Stanislas Pondiczery at the Royal Insitute of Poldavia. The hope was that someday a document could be signed ESP RIP [7].

The distinguished music and audio writer and critic Edward Tatnall Canby wrote [25] how Tukey befriended him at the Princeton Graduate School:

\footnotetext{
Finally, by a fluke, I ended up of all places at the math and physics table .... To my astonishment the conversation at this table was a delight and in no time I was making new friends .... In no time at all, a stout and genial genius called The Tuke, ..., decided that my "system" should be improved - first via a baffle .... It was Dr. John Tukey, The Tuke, who persuaded me to try to build my own separate amplifier, of course under his tutelage.
}

Tukey came to Princeton to study chemistry. During his first year he was a Laboratory Assistant in sophomore chemistry, but complained that he could not be a Demonstrator in Physical Chemistry despite having been one at Brown. He spent a lot of time in Fine Hall which then housed both the University's Mathematics Department and the School of Mathematics of the Institute for Advanced Studies.

Tukey attended lectures by Aurel Wintner, "On asymptotic distributions and infinite convolutions." Notes for the course were taken by R. P. Boas, F. Smithies and Tukey, "with sympathetic encouragement from C. C. MacDuffee." (JWT used that same style in the labeling of the notes of his 1963 Mathematics 596 course at Princeton [81].) He also attended M. Morse's lectures on symbolic dynamics in the spring of 1938. He said that Steenrod and he did their best to "keep Morse honest" [7]. (Keeping people "honest" is an expression JWT liked to use.) In a course given by A. W. Tucker in 1938, every time Tucker gave a definition of a combinatorial manifold, JWT would come up with a counterexample, hence the Tucker remark, "It ended in a draw" [75].

In the spring of 1938 JWT passed the doctoral comprehensive exam, and obtained an A.M. in Mathematics. In 1938 he published two mathematics papers. For his second year of graduate studies Tukey was awarded the Jacobus Fellowship, the top fellowship in the Graduate School.

At this point JWT was working in both analysis and topology. He liked topology, for "Topology exists to provide methodology for large chunks of the rest 
of mathematics" [7]. His thesis, "On Denumerability in Topology," was submitted in 1939, nominally under the supervision of Solomon Lefschetz. Part of it appeared in 1940 as No. 2 of the Annals of Mathematics Studies [78]. Of the thesis he remarked that he was seeking to extend convergence techniques to general spaces. Also appearing in the thesis is the Tukey Lemma [78]: "every nonempty collection of finite character has a maximal set with respect to inclusion." This lemma is equivalent to the Axiom of Choice. JWT further baptizes Zorn's Lemma in the thesis.

Tukey's work on topology was used extensively by Isbell in his book, Uniform Spaces [48] and is also basic in Howes [46]. Norman Howes wrote us [47]:

Of course John Tukey did not invent uniform spaces, but it seems to me that his formulation of the concept is the most useful. The first formulation of the concept, that still remains the most well known, was what I would call a generalization of the geometric properties of a topological group .... Tukey's formulation, on the other hand, is a generalization of a metric space, which allows one to reason about uniform spaces almost as if they were metric spaces .... But Tukey's contribution in this area went beyond showing us how we should think about uniform spaces. His insight was almost prophetic. He sensed that the most interesting uniform spaces were the ones that were fully normal .... Tukey predicted that the fully normal uniform spaces would play a major role in mathematics, and indeed they have.

...

Finally, Tukey intuitively seemed to understand the importance of the relationship between convergence and uniform structure. His early terminology and his arguments were not as elegant as the vocabulary and arguments we use today, but the central ideas were all there. I believe that if John Tukey had been able to express these ideas more clearly to the mathematical community that he would have received more recognition for his fundamental contributions in this area.

The British topologist D. H. Fremlin wrote [37]:

Of course Tukey's ideas on partial orders did have great influence on me. This was really through J. R. Isbell. ... I still believe that Tukey's notion of cofinal equivalence gives fundamental insight into some important questions in set-theoretic analysis.

Halmos [43] includes Tukey's thesis among mathematics books that were influential in the period 1888-1988. He says that it is slim, "but packed a punch in its day." He continues that "it is in effect a competitor to Bourbaki's approach to topology." Halmos ends by remarking that some of Tukey's friends at the Graduate School formed a society with the name Gegen Tukey Sport und Turnverein.

Tukey's name lives on in topology: "Galois-Tukey connections," "Tukey equivalence," "Tukey reducibility," "the Tukey theory of analytic ideals," "Tukey ordering," as well as "Tukey's Lemma."

At the party celebrating the completion of their graduate studies JWT and Robert Eddy became notorious for serving milk rather than the traditional beer [8]. (Robert Eddy was the father of our statistical colleague Bill Eddy, but Bill does not remember his father being a teetotaler.) 


\section{Princeton: The early faculty years.}

One of the guys, a fella named John Tukey, said: “I don't believe you can read, and I don't see why you can't talk. I'll bet you I can talk while counting to myself, and I'll bet you can't read." ... By that experience Tukey and I discovered that what goes on in different people's heads when they think they're doing the same thing-something as simple as counting — is different for different people.

R. P. Feynman [36]

Tukey was H. B. Fine Instructor of Mathematics at Princeton for the years 19391941. There he came to know the physicist Richard Feynman, then a graduate student. Tukey appears in various of the books by and about Feynman. For example his biographer Mehra [57] remarks that Feynman "discussed many ... ideas with fellow graduate students, like Bill Woodward and John Tookey [sic]." One story relates to keeping time. Feynman knew that he could keep track of time at the same time as he was reading, but not while he was speaking. He presented this as a challenge, whereupon JWT showed the reverse, that he could keep track of time and speak simultaneously. Both Feynman and Tukey were renowned for being able to do complex numerical computations in their heads.

Reference has already been made to how much Tukey enjoyed the time he spent at Princeton in those early years. In 1939 Feynman and Tukey, together with Bryant Tuckerman and Stone, were hexaflexigators. This group formed following the discovery of certain origami-like objects by the British mathematician Arthur Stone. Stone had a narrow English binder but, being in the U.S., was forced to purchase wider sheets of paper. He cut off the right margins so that they would fit the binder. Being left with strips of paper, he amused himself by folding them. Thus he discovered hexaflexagons, polygons folded from paper with the property that one can flex or turn them inside out to reveal hidden surfaces. Specifically, by pinching opposite corners new hexagons with different sets of triangles are exposed.

A mathematical theory of flexagons was worked out in 1940, by Tukey and Feynman. It was never published, but parts apparently have been rediscovered. Among the results developed is an asymptotic formula for the number of different hexaflexagons with $n$ sides [34]. Feynman created a diagram that showed all the possible paths through a hexaflexagon [38]. Perhaps this was an important stimulus in Feynman's development of the Feynman diagrams of quantum physics.

Tukey's contributions to the topic live on in the terminology: Tukey triangles, the Tukey triangle network, Tukey polygon strips, Tukey hexagons (see H. V. McIntosh's website: delta.cs.cinvestav.mx/ mcintosh). In the late 1940 s Tukey approached a toy company about marketing flexagons, but this did not come to pass. The American Philosophical Society archive of Tukey's papers contains many of the original forms that were created.

In 1942 Stone and Tukey proved and generalized the Ham Sandwich Theorem, to the effect that, given a piece of ham and two slices of bread, it is possible to find 
a single plane bisecting each of the volumes. This work is sometimes known as the Stone-Tukey Theorem.

In 1941 Tukey was appointed Assistant Professor of Mathematics at Princeton. He further began to take on the many professional responsibilities that would be with him throughout his career. He listed his interests in American Men of Science of 1942 as: point set topology and analysis. As suggested in the introduction, Tukey's list of interests would shortly grow.

\section{The war years.}

By the end of late 1945, I was a statistician rather than a topologist.

6.1. The Fire Control Research Office. Tukey described himself in the period 1938-1941 as a mathematician in the narrow sense. Indeed, Mosteller [60] writes of having asked him a statistical question at the graduate dormitory, to which Tukey answered "I don't do statistics."

Things were changing. Even six months prior to Pearl Harbor, Princeton University girded for the inevitability of U.S. entry into World War II. In May 1941, Tukey joined the Fire Control Research Office (FCRO) located in an office building at 20 Nassau Street. This was a department of the University supervised by the mathematician Merrill M. Flood (later credited with co-discovery of the Prisoner's Dilemma). Tukey's title there went from Consultant to Assistant Director during the years 1941-1945. Among those working in this office were G. W. Brown, E. Cuffey, W. J. Dixon, L. L. Rauch, A. M. Mood, Virginia Mosteller and C. P. Winsor. Virginia served as Flood's secretary until her husband was sent to NYC to help establish the Strategic Bomb Group of Princeton. When F. Mosteller returned to graduate school at Princeton at the end of the War, she became Flood's secretary again. Recreations of the FRCO group included tea and kriegspiel at Mood's house [58].

The FRCO supported the work of the National Defense Research Committee chaired by J. B. Conant. The Princeton office was concerned with many aspects of artillery fire control including mathematical optics, ballistic behavior of rocket powder and stereoscopic height and range finders. A particular concern of the FRCO was the precision of machine gun fire from a B29 bomber [3]. The Office had one of the first IBM card machines capable of performing multiplication.

6.2. Time series and code breaking. A letter from MIT mathematician Norbert Wiener dated June 20, 1942 indicates that Tukey was already interested in the autocorrelation analysis of time series at that time. The letter is reproduced in [18]. The mathematician Saunders Mac Lane [55] writes about how Tukey provided considerable stimulus to L. Cohen (a Princeton-trained topologist) who was working on the problem of computing leads for machine guns aiming 
at fighter planes. Cohen was working in the Applied Mathematics Group at Columbia.

Tukey was involved in code-breaking during and after World War II. W. O. Baker [10] said:

John was indeed active in the analysis of the Enigma system and then of course was part of our force in the fifties which did the really historic work on the Soviet codes as well. So he was very effective in that whole operation.

6.3. Statistics. While working at FCRO, Tukey had many meals and interactions with Charlie Winsor. These proved a major inspiring influence on Tukey's ensuing career interest in data analysis. Winsor was a Harvard engineer, but because of his Ph.D. in physiology he was known as an "engineer-turned-physiologistturned-statistician." To quote Tukey: "It was Charlie and the experience of working on the analysis of real data, that converted me to statistics" [99].

JWT called himself a statistician by the end of 1945. His first published statistical paper is Scheffé and Tukey [69]. It is revealing to know just what JWT then viewed as the subject of statistics. One finds him saying [79]:

Statistics is a science in my opinion, and it is no more a branch of mathematics than are physics, chemistry and economics; for if its methods fail the test of experience-not the test of logic - they are discarded.

He also remarks that statistics is "something that had the purpose of being used on data" [35]. JWT contrasted these ideas with those of the mathematician Walther Mayers, who preferred the situation "that if I say $g_{i k}$ has certain properties, it really does" [87].

In 1965 JWT wrote his view of the structure of mathematics. He saw its components as [83]:

Abstraction, calculation, free assembly, logical solidity and security, precision, quantitativeness and symbolism.

JWT indicated that he learned statistics by reading the Journal of the Royal Statistical Society Supplement, and he often recommended this approach to others.

In the 1948 issue of American Men of Science Tukey listed his interests as point set topology, fire control equipment, military analysis, mathematical and applied statistics. This list remained in his entry as the years passed.

\section{The industrial world-Bell Telephone Laboratories.}

Where could I ever find another Bell Labs?

JWT to his wife Elizabeth [77]

In early 1945 John, "Mr. Tukey," began his long association with Bell Telephone Laboratories, Murray Hill, New Jersey. Bell Labs is perhaps the foremost industrial research organization that the world has known and Tukey never left. 
In succession he was: Member of Technical Staff 1945-1958, Assistant Director of Research, Communications Principles 1958-1961 and Associate Executive Director, Research-Information Sciences 1961-1985. He retired from both the Labs and Princeton in 1985 at age 70, these retirements being mandated under Federal law. At Princeton he became Senior Research Statistician.

At the Labs JWT started out working for Henrik Bode on the development of the Nike antiaircraft missile system in whose research and development the Bell System played a principal role [33]. Tukey had gone to the Labs as a "computer topologist" [5] with the thought of working on the Nike project only, as an outgrowth of Fire Control Research Office work, but ended up working much more broadly.

At JWT's retirement event W. O. Baker, now Retired Chair of the Board of Bell Labs, remarked [12]:

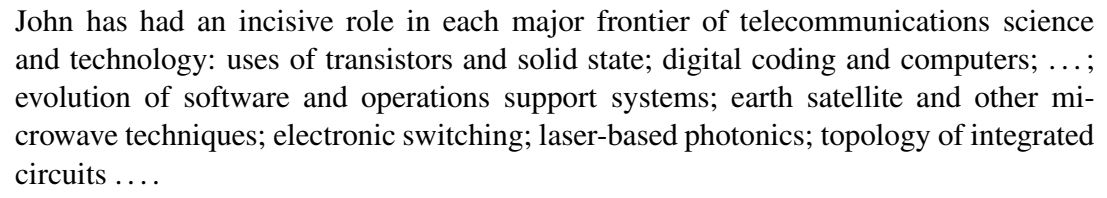

At the Labs John gave courses, cross-fertilized researchers, attracted renowned visitors, reviewed, wrote many technical memoranda, made personnel and project decisions, enlivened seminars. To put it directly, he had a presence. To provide an example, Harry Hart, one of the Labs workers responsible for patent applications, also lived in Princeton. During the drives between Princeton and Murray Hill, Hart would probe Tukey with questions about the science involved in his current patenting work. I can tell you from personal observation that Tukey invariably knew the answers, over a wide array of esoteric topics.

He received patents, for example, one with J. R. Pierce and C. Shannon [63] for a cathode ray device. (All three coinventors would in due course be awarded National Medals of Science.) There were influential papers, for example, Bode, Mosteller, Tukey and Winsor [15] on being a scientific generalist. Of this particular paper Arthur Burks [22] writes how much it influenced the way that the graduate program in Computers and Communications at the University of Michigan was established and organized.

The development of the cepstral technique for estimating the depth of seismic events was carried out at the Labs with B. P. Bogert and M. J. R. Healy [16]. One can also mention Tukey's work with Atal, Chang and Mathews on the vocal tract [9]. His Bell Labs and later assistant, Mary Bittrich, has told the story of how JWT's needs for tabular displays in papers led to the development of the $t b l()$ function in the Bell Labs developed UNIX typesetting package troff [12].

JWT worked with I. C. Ross at the Labs on the project to index the literature of statistics $[67,68]$. Indeed, the Labs supported much of Tukey's more academic research, as he has acknowledged. Bell Labs provided him with practical problems, 
access to the fertile minds of many brilliant engineers and scientists and computing and secretarial support of which he made such effective use. As W. O. Baker's remarks above show, the Labs lauds him as one of their most important and influential workers.

\section{The academic world-Princeton.}

... the first time I was in a statistics course, I was there to teach it.

8.1. Some chronology. In September 1945 JWT came back to a half-time position as Assistant Professor of Mathematics at Princeton. At that time he was still doing some mathematics, and in particular he was preparing many pieces for Mathematical Reviews. He was recorder of the mathematics session at the 1946 Princeton Bicentennial Conference. He was a Member of the Council of the American Mathematical Society in 1947. Yet he had become a statistician and begun to move steadfastly into the statistical community. He was a Councilor of the Biometric Society in 1947. He was the Central New Jersey Representative of the American Statistical Association in 1948. He provided answers to statistical queries sent to Biometrics and The American Statistician. He turned to producing a steady stream of research papers in statistics.

At Princeton, JWT was a member of the Section of Mathematical Statistics, in the Mathematics Department. The Section was headed by S. S. Wilks. The combination of Tukey and Wilks was a potent force for statistics for many years. On Wilks' untimely death in 1964 Tukey wrote an affectionate memorial [82].

In the 1947 appraisal for Tukey's possible promotion to Associate Professor and tenure the Cornell (later Princeton) probabilist W. Feller [5] wrote:

\footnotetext{
Tukey's interests and activities cover an incredibly wide range. He is rich in ideas, has a fifth sense for new possibilities, and develops an infinite amount of energy. He works almost at the same time on supersonic flow, computing machines, theoretical statistics and special biometrical problems. The main value of his papers lie in the lucid exposition, and in the ease with which Tukey popularizes new ideas and combines methods and results from different fields.
}

Needless to say Tukey was awarded the promotion. In 1948-1949 he held a Guggenheim Fellowship and worked out "polykays" in the Fine Hall lounge. These are unbiased estimates of the expected values of particular polynomials in random variables. A lot of algebraic manipulation and perseverance was required. The word "polykay" has been described as "linguistic miscegenation" by Kendall and Stuart [52] because of its combining a Greek prefix with a Latin suffix. (Tukey did it again later with the word "polyspectrum.")

JWT became Professor of Mathematics in 1950 and held that position until 1966, when the Statistics Department was formed. 
During his career he wrote a number of articles describing and analyzing the life of applied mathematicians and statisticians. In 1955 his paper "Mathematical consultants, computational mathematics and mathematical engineering" appeared in the American Mathematical Monthly.

M. Schwartzschild, L. Spitzer (Princeton astrophysicists), J. Wheeler (physicist) and Tukey met for lunch regularly in the 1950s to share ideas on science and the state of the world. Tukey called their group the "Chowder and Marching Society" [106]. Wheeler goes on to say:

John Tukey, like John von Neumann, was a bouncy and beefy extrovert, with interests and skills in physics as well as mathematics.

A surprising JWT anecdote concerns the history of computer development. The classic work by Burks, Goldstine and von Neumann [23] states in the Preface: "The authors also wish to express their thanks to Dr. John Tukey, of Princeton, for many valuable discussions and suggestions." When I asked Arthur Burks just what Tukey did, he wrote [22]:

John Tukey designed the electronic adding circuit we actually used in the IAS Computer. In this circuit, each binary adder fed its carry output directly into the next stage without delay. As I recall, experimental measurement showed that the complete carry took about 4 clock pulses. And this was the circuit actually used because it was reliable and much simpler than the alternative.

Tukey did not allow himself to be nominated for high offices in too many societies [60], but he was Vice President of the American Statistical Association for the period 1955-1957. In 1956 he set up the Statistical Techniques Research Group (STRG) at Princeton. The first electronic computer on the Princeton campus, not counting von Neumann's at the Institute, was very possibly the IBM 650 at STRG's Gauss House on Nassau Sreet. The STRG had many important members and visitors and its technical reports were highly influential at that time.

For the period 1951-1956 JWT was Supervisor, Military Systems Analysis at Princeton's Forrestal Research Center. He was instrumental in setting up a branch of the Institute for Defense Analysis (IDA) on the Princeton campus in 1960. (IDA moved off campus in 1970 during the period of student protests over the war in Vietnam. Tukey served on its Board of Trustees for decades, though unmentioned on his CV.)

JWT was Vice President of the Society for Industrial and Applied Mathematics in the late fifties. For the period 1960-1961 he was President of the Institute of Mathematical Statistics. One innovative step he took as President was to carry out a survey on the IMS members' feelings on the need for a separate journal of probability. The results were in favor, but The Annals of Probability did not appear until 1973.

In the early sixties JWT was Advisor to the Econometrics Project at Princeton, headed by Oskar Morgenstern. Among other accomplishments that circumstance 
led to the appearance of the book Spectral Analysis of Economic Time Series (1964) by Clive Granger in association with Michio Hatanaka.

A Statistics Department was created at Princeton in 1966 with JWT as first Chair. His appointment as Professor of Statistics lasted until his retirement in 1985. From 1976-1985 he also held the Donner Chair of Science. In 1978 JWT reviewed the history of Statistics at Princeton in an essay [91].

As previously mentioned, Tukey had been involved in scheduling at the New Bedford High School. It is therefore no surprise that from 1945 to 1970 he chaired Princeton University's Schedule Committee. It was said that he would lie flat on his back and call out answers to scheduling problems. (On various occasions he called himself a "horizontal consultant.")

Tukey made other contributions to the administration of the University. $\mathrm{He}$ developed a method of merging class scores from the sections of Princeton's larger undergraduate classes. In addition Tukey and Sam Wilks sought to assist the Princeton football team with rudimentary data analyses of game statistics.

From 1960 on John received many honors. He received his first honorary degree (one of seven) from Case Institute of Technology in 1962. The words of the citations at the ceremonies included:

A self-described "miscellaneous type" in an age of specialization ....

Princeton University, 1998

He has pioneered developments in fields that intersect with every department in mathematics facilities....

University of Waterloo, 1999

\subsection{Teaching and Students.}

Well, what I think you need is folk dancing.

JWT to Leo Goodman, 1949

Tukey's teaching style was somewhat on the oblique side. Indeed, some wondered whether he wasn't being deliberately obscure. Perhaps his own educational background led to his sometimes treating others a bit like students in conversations. My personal impression is that he wanted the people with whom he interacted to figure things out on their own, to the degree possible. One Christmas Tukey gave his students books of crossword puzzles as presents. Upon examining the books the students found that Tukey had removed the puzzle answers and had replaced them with words of the sense:

Doing statistics is like doing crosswords except that one cannot know for sure whether one has found the solution.

Fred Mosteller has said, "He always did two things: took a pass at the problem I asked him about and then he'd always suggest something else, something entirely different to work on" [3]. 
In the late 1940s a first-year graduate student, Leo Goodman, got asked by Tukey how things were going. When Leo replied, "I don't know," JWT gave him an oral exam on the spot. Then after a bit of reflection, hand on chin, Tukey made the remark quoted above. For more than a decade John was a folk dance instructor, and that is how he met his future wife, Elizabeth. Later Leo had another experience indicative of Tukey's teaching style. Tukey had received a postcard with a statistical query. He suggested that Leo deal with it. This led to Leo's first statistical publication in The Annals of Mathematical Statistics (1949).

The Applied Statistics Seminar which began in 1946, was an important part of the education of the Princeton graduate students. It was the tradition of the seminar that participants, rather than remain silent, contribute what they could, even if it were confused or incorrect. Remarks were never to be held against the one speaking out. Another tradition was that the presenter need not have a solution to the problem being presented.

The courses JWT presented were state-of-the-art, indeed introducing the art in many cases. Special topics included: Monte Carlo, fractional replication and time series. Major investigators, such as Cuthbert Daniel, joined in.

John's interactions with students often took place at the house on Arreton Road, particularly on weekends. Notably Tukey held gardening to be a social activity. This resulted in his advisees sometimes having to compete with the power mower (or saw) to be heard. Others would weed flower beds.

Tukey's busy schedule obliged him to develop clever strategies for managing his time. He would schedule four classes each week. From the four available he then picked the three times that were the most convenient for the week at hand. Another method he employed was to schedule classes for, say, 2-4 Tu/Th instead of the usual 2-3:15 pm and then sometimes skip a class or at other times run it longer.

Princeton created an undergraduate concentration in statistics in 1970. Undergraduate students influenced by JWT include: Bill Cleveland, David Donoho, Bill Eddy, Don MacLaughlin, Charles Smith, Paul Tukey (a fifth cousin), Roy Welsch. Some of JWT's undergraduate courses were famous, particularly Statistics 411. The content of the course changed a great deal from year to year. The attendees included graduate students and senior researchers, with the undergraduates given precedence in asking questions and seating.

It is revealing to think back to what it was like to be Tukey's student. (His Ph.D. students are listed in Appendix C.) It is clear that he gave his students a substantial head start on their research careers. We learned a lot of practical tips from watching: things like carry-on baggage for air flights, gallon-size refrigerator bags for protecting notes and transparencies, coloring and displaying viewgraphs, employing two overhead projectors in tandem, telephone usage, multi-colored pens, multi-tasking at seminars, quality of remarks, student supervision, learning the basic science, assistance of others. My personal experience was that he put students down a bit when they were over-cocky, and built them up when they were down. 
When my thesis was almost finished, John asked what thoughts I had concerning my future career. Answering quickly, I said that I found the professional lives of Wilks and John himself a bit unappealing as they spent all their time working and seemed to leave little time for anything else. Tukey's reaction was to propose Willy Feller as a role model. I thought about Feller, and he did have a good life. On that basis I happily went on into the academic world. Of course, at this point in my life I myself am just plain too busy, but willingly so.

\section{Public service.}

It is my guess that statisticians Frederick Mosteller (Harvard) and John Tukey (Princeton) have served on or assisted more technical committees than anyone else alive.

9.1. The quiet patriot. Tukey's service during WWII at the Fire Control Research Office was just the onset of lifelong support to national defense. This service largely does not appear in Tukey's curriculum vitae. Once his professional papers are organized and made available, some of these activities will become known. Others may prove untraceable.

The Princeton University Physics Department was highly involved in the design of the atomic and later hydrogen bombs. In 1945, at the behest of General Groves, the chairman of the Physics Department, Henry Smyth, wrote a book Atomic Energy for Military Purposes, which revealed the Manhattan Project to the American people. Mathematicians and early computers were important to the design of nuclear weapons, since they were needed to test the feasibility of a design through calculations, hence the call to Tukey and others when Ulam and Teller designed the first H-bomb. Princeton University continued to be involved in both nuclear weapons and energy development thereafter, under Project Matterhorn. The weapons program was headed by Tukey's friend John Wheeler, and the energy program by another friend, Lyman Spitzer.

Tukey organized folk dances during visits to the uranium enrichment facility in Oak Ridge, Tennessee during the early 1950s. Such visits may have been to support the functioning of its computer, the Johniac (named for von Neumann). The computer development project in which John von Neumann had first enlisted Tukey during late 1945 was funded by the Defense Department. John von Neumann was himself a Commissioner of the Atomic Energy Commission at the time of his early death in 1957. The development of nuclear weapons by Stalin's Soviet Union and the memory of the 1941 debacle at Pearl Harbor made intelligence gathering a high national priority. With unmatched expertise in communications and computing research, Bell Labs was enlisted to support national security endeavors. In 1957, Tukey's valued friend William O. Baker, later head of Bell Labs, headed a committee that recommended to President 
Eisenhower a comprehensive plan to intercept Soviet communications, in due course a path followed by the National Security Agency (NSA). Tukey joined Baker and Princeton statistical colleague Sam Wilks on NSA's Science Advisory Board in late 1952. During the mid-1950s, Tukey traveled to England several times for meetings with British defense officials [5, 41]. Starting in 1960, he served on the President's Science Advisory Committee (PSAC) and advised five Presidents. While some of Tukey's work notably pertained to chemical pollution, PSAC also rendered advice on many national security matters.

There was other work on defense projects. Project Matterhorn was a classified project, instituted at the Forrestal Research Center of Princeton University in 1951 to design thermonuclear weapons. It was started by L. Spitzer and initially directed by J. Wheeler. Tukey contributed to its work [106]. In 1952 Tukey was asked to become a member of the National Security Agency's Science Advisory Board [5]. He was also a member of the Science and Technology Advisory Panel of the Central Intelligence Agency (CIA) [26].

The Nike Missile. In January 1945 the U.S. Army Air Force contracted with Bell Labs to develop a defense system against the foreseen threat of high-flying bombers. Perhaps because of his work with the Fire Control Research Office, Tukey was hired by $\mathrm{H}$. Bode to help with this major new national security mission. In due course, this project became known as Nike, the first widely deployed surface-to-air missile. It required a systems solution to which Tukey was so profoundly suited: the integration of ground-based tracking radar, computers, and communications with an airborne missile. Five months of intensive work, by a group including W. A. McNair, H. W. Bode, G. N. Thayer, B. D. Holbrook and Tukey, resulted in a written proposal "A study of an Antiaircraft Guided Missile System," presented to the Government in July 1945. Bell Laboratories was then given full responsibility for the missile's development. Holbrook and JWT did the aerodynamics, the trajectory and the warhead, sometimes by paper and pencil $[34,35]$. Quoting JWT, "The question is what path would the missile take to get the farthest out possible and still have enough speed to manoeuver?" [35]. By October 1946, Tukey was in New Mexico observing Nike missile firings [5].

Bode was Tukey's best man at his wedding and wrote, in connection with Tukey's 1947 tenure case [5]:

He has a great fertility in ideas, open-mindedness toward heterodox solutions, and penetration in reaching the heart of complex and abstruse situations. These are wedded to unusual energy, which permits him to carry out two or three times the load of ordinary men. It is safe to say that he has made an irreplaceable contribution to national defense.

Bode was possibly referring to the Nike system.

The Technological Capabilities Panel. Tensions with the USSR were high during the middle 1950s, Krushchev succeeding Stalin. The United States became concerned about the possibility of an effective surprise nuclear bombing attack. 
One event that contributed to the suspicion was the Soviet Union's flying the same planes by more than once at a Red Air Force Day [24]. To guard against the possible threat, in 1954 President Eisenhower empaneled a committee of scientists, headed by MIT President J. R. Killian. It consisted of a steering group (chaired by Killian), three project panels, a communications group and a military advisory committee. Project 3 concerned collection of technical intelligence. It was chaired by E. H. Land, of Polaroid camera fame, and included the astronomer J. G. Baker, the chemist J. W. Kennedy, the engineer A. Latham, Jr., the Nobel laureate physicist E. M. Purcell and Tukey [24, 64]. Project 3's group used to joke that they could hold a meeting in a taxicab. They recommended the adoption of "a vigorous program for the extensive use ... of the most advanced knowledge in science and technology."

What might Tukey have contributed specifically? Project 3's section of the report includes the words:

\begin{abstract}
We must find ways to increase the number of hard facts upon which our intelligence estimates are based, to provide better strategic warning, to minimize surprise in the kind of attack, and to reduce the danger of gross overestimation or gross underestimation of the threat.
\end{abstract}

The group's proposal was to create a high-flying spy plane. The development of the U-2 followed quickly.

President Eisenhower required that the CIA, not the Air Force, have responsibility for the operation, that the pilot be a civilian, and that the President give final permission for each flight. The first flight over the USSR was in 1956 and the last in 1960, when Francis Gary Powers' craft was shot down.

In 1957 Eisenhower formed the President's Scientific Advisory Panel (PSAC), partly in response to the effective way that the scientists had dealt with the "bomber gap".

Nuclear Weapon Tests Treaty Negotiations. In 1959 JWT spent a month in Geneva, Switzerland as a U.S. Delegate to Technical Working Group 2 of the U.S.-USSR Conference on the Discontinuance of Nuclear Weapon Tests. His expertise, in part, concerned the time-series problem of distinguishing earthquakes from nuclear explosions, given data in part consisting of seismograms. Elizabeth Tukey remarked:

John had pulled some rabbit out of the hat that made it clear that nuclear underground testing could take place and not be noticeable up on the surface.

Elizabeth Tukey [39]

suggesting that JWT played a highly influential role. Details of cavity decoupling were later developed by Albert Latter of Rand Corporation. The whole matter of (partially) masking a test very much startled the Russians [17].

JWT described that period in Geneva as a "time of stress ... like a utilities rate case." In 1967 he wrote [86]: 
...my experiences with Geneva ... where the political conference set up technical working groups in the hope that the scientists would settle some of the questions that the politicians could not .... The politicians' attempt to evade responsibility failed, as was inevitable.

Unfortunately the working out of verification procedures to ensure compliance with a ban on nuclear weapon tests in all environments proved to be intractable at that time. Concerning the problem of discriminating earthquakes from nuclear explosions, one method of inferring the occurrence of an explosion, rather than an earthquake, is by plotting the signs of first motions observed at scattered seismometers. In an explosion the first motions tend be of the same sign. In an earthquake they will lie in quadrants or some related design. JWT's report [80] addresses the problem of improved estimates of first motion.

Another method is to estimate the depth of the event, deep events being necessarily earthquakes. The Bogert-Healy-Tukey technique of cepstral analysis [16] was developed in this connection. It supposes that the recorded time series contains an echo of the basic signal, in addition to the basic signal in the time series recorded. The presence of an echo leads to a ripple on the signal's power spectrum and hence frequency domain Fourier studies.

Other. In 1961 Tukey chaired the West Ford Panel. This concerned the failure of an experiment designed to improve shortwave communications by launching into orbit millions of copper threads to serve as reflector antennas.

JWT's work on fast Fourier transforms [81], expanded on in the paper [18], received crucial stimulus when Tukey interacted with R. Garvin of IBM at a PSAC meeting in 1963. The meeting itself concerned seismic detection of nuclear tests and acoustic detection of submarines; see Cooley [29].

Once, in the mid-sixties, I asked Tukey whether he had any interest in visiting the USSR. He replied, "Perhaps as a member of a delegation."

Support and consulting. Tukey made valuable contributions to many critical defense and intelligence programs [53]. In particular, he was adviser, consultant and committee member for both the CIA and the NSA. He attended many of the Army's design conferences, initiated by Sam Wilks. In the mid-fifties he visited the British GCHQ Government Communication Headquarters in Cheltenham [41]. In 1965 he received the Wilks Award when its criteria still involved contributions to military research.

Both the Army Research Office and the Office of Naval Research supported Tukey's research.

9.2. Government advising. Tukey's defense work has already been referred to. A long list of other activities covers many fields.

In 1949 a "Memorandum on statistics in the Federal Government" came out in The American Statistician. In the late fifties he was a member of the National 
Bureau of Standards's Ad Hoc Advisory Committee that led to the appearance in 1964 of the highly influential Handbook of Mathematical Functions (edited by M. Abramowitz and I. A. Stegun).

For the years 1960-1963 Tukey was a Member of the President's Science Advisory Committee (PSAC). An intriguing aspect is that he once said of that work that it involved "no statistics." This is notable because Tukey seemed to find statistics problems everywhere. In 1962 he was a Member of a PSAC Behavioral Sciences Subpanel. For the period 1962-1964 he was a member of the NSF's Scientific Information Council.

During 1970-1971 Tukey was a member of the President's Commission on Federal Statistics. In the mid to late sixties he was heavily involved with the National Halothane Study. This study was statistically pathbreaking in many ways, including its studies of tabular data and of survival analysis.

The environment. Tukey's work concerning health and the environment was particularly important over the years. In 1964-1965 he chaired a PSAC panel on environmental pollution. It brought out a report Restoring the Quality of Our Environment. This was a landmark on environmental policy. It called for polluters to pay for their emissions via taxes and affirmed no right to pollute. For the period 1968-1971 Tukey was a member of the President's Air Quality Board. In 1970 it published the report Cleaner Air for the Nation. This work possibly led to Tukey's being a Member of the U.S. Delegation to the U.N. Conference on the Human Environment in Stockholm in 1972. During the years 1971-1972 he chaired PSAC's Panel on Chemicals and Health. That Panel prepared the report Chemicals and Health.

There were other reports on environmental issues: in 1976 one for the National Academy of Sciences, Halocarbons: Environmental Effects of Fluoromethane Release and in 1978 one reviewing the results of attempts at weather modification [20]. In 1979 he chaired the NRC/NAS Committee on the Impacts of Stratospheric Change and in 1991 he was a member of the Oversight Review Board of the National Acid Precipitation Assessment Program (NAPAP). For ten years (1981-1991) he advised the Health Effects Institute on the design of studies. This organization, cofunded by the auto industry and the US EPA, conducts health studies on the potential effects of auto air pollution upon human health.

It is perhaps worth mentioning how Tukey liked the committees he chaired to proceed: he thought it was important to have the committee start work the evening before the main sessions. From personal experience it was a highly effective structure, leading to an organized, gentle experience. Another notable occurrence was that a clear completion seemed to take place at the end of the meetings, partly because Tukey could carry through fairly complex analyses in real time.

Education. John Tukey had a long-standing interest in the effectiveness of education. From 1965 on he was a consultant to the Educational Testing Service (ETS), Princeton. There he associated with Ledyard Tucker and Fred Lord. He 
was also a consultant to the Education Commission of the States (ECS). Starting in 1965, he was Chair or Member of a succession of Advisory Committees of the National Assessment of Educational Progress (NAEP). L. Cronbach, R. Tyler, R. Abelson, L. V. Jones and JWT met often in the late sixties to guide NAEP's formation [50]. (NAEP is a long-term program of assessing what the inhabitants of the U.S. can do, as measured by their performance on exercises at various ages. It further wishes to measure changes in performance. It proceeds by sampling pertinent populations of schools, students and people.) F. Mosteller chaired the Statistics Advisory Committee for 8-10 years, and the first report came out in 1970.

JWT also involved himself with week-long "Short Courses" through the Princeton-based University Associates in the 1970s and 1980s. These included "The Practice of Spectrum Analysis" with Bloomfield, Brillinger and Cleveland [14] whose attendees included Dick Hamming and Ed Jaynes. He also gave a 1975 Short Course on Data Analysis with David Hoaglin at the ASA Annual Meeting and the University Associates "Advances in Data Analysis" with Bloomfield, Braun and Siegel.

Tukey further participated in a variety of courses at Bell Telephone Laboratories. For example, there was a collaborative program for new engineers with NYU.

The Census. Tukey advised the Census Bureau throughout much of his career. In 1980 the step of adjusting the raw census counts to obtain an "improved" estimate became highly political and got tangled up in the adversarial setup of the U.S. legal system. JWT testified before committees of the House of Representatives a number of times and served as an expert witness in the litigation. There were papers and discussion at the 1982 Detroit Meeting of the ASA. Ericksen, Kadane and Tukey's paper “Adjusting the 1980 Census of Housing and Population" [32] appeared in 1989. The matter recurred with the 1990 Census. Others of his writings on the subject are: [96, 100-102].

In a 1992 court case S. Fienberg, J. Rolph and JWT, as well as the state of Florida and the cities of Atlanta and New York, were on the side for adjustment, P. Meier and D. Freedman and the Secretary of Commerce and her Department were opposed to adjustment. JWT supported a smoothing approach to adjustment, possibly because the technique had been so successful in election forecasting. (Election projection is returned to later.) The testimonies may be found in [27].

It is revealing that in his testimony at the 1992 trial JWT describes his fields of specialization as including: time series, robust techniques, exploratory techniques, analysis of variance and regression.

A court case. In the mid-nineties JWT became involved in the legal world on another matter. The issue was whether a black American in New Jersey was more likely to be given the death penalty than a white one. Some regression analyses had been carried out, and a scientific expert was sought. A Special Master 
was appointed, and he involved JWT as his consultant. The report submitted suggested that the inclusion of too many variables in the models that had been employed made the earlier conclusions unreliable, and that there was no evidence of bias [104, 105].

\subsection{The Kinsey Report.}

Most Americans could hardly have cared less what academics thought. They wanted to hear what Kinsey had found.

J. H. Jones [49]

In 1950, following a request to its Commission on Standards, the American Statistical Association assembled a committee to review the statistical problems in Alfred C. Kinsey's work on sex research. This followed the very substantial criticism of the statistical aspects of Kinsey's approach as presented in his 1948 book, Sexual Behavior in the Human Male. Kinsey's work was supported by the Rockefeller Foundation, and the Foundation had become concerned with the criticism the work was generating and in particular whether to support the work involved in a corresponding volume on the human female.

The ASA chose as members for the committee W. G. Cochran, F. Mosteller and Tukey. After substantial negotiations over the terms and protocol the Committee visited Kinsey's Institute for Sex Research in October, 1950. Things started badly. Walking over to the Institute, the three men got to singing a Gilbert and Sullivan song. Kinsey greeted them briskly and showed them into a room in which they might work. In the room Mosteller, hoping to lighten things up, suggested they finish the song. Apparently the trio's singing was easily heard by the workers in the Institute. An angered Kinsey rushed in and gave the Committee a loud rebuke. Still the Committee proceeded to collect information and to have their own sexual histories taken by Kinsey and his staff.

Many things did not go well. In particular, following a dinner at the Kinsey home Kinsey's wife, Clara, said, "I never fed a group of men that I would have so liked to have poisoned .... Tukey was the worst" [49]. According to Mosteller [60] Tukey had great respect for Kinsey's stick-to-it-iveness and his willingness to take on a very extensive field of work. In keeping with this, the Committee wrote a carefully balanced, fair appraisal of the Kinsey study, noting things done well while suggesting things that could be done better in future work. Tukey's archive of professional papers at the American Philosophical Society contains much about this appraisal.

The Committee was concerned with the sampling methods and in particular with the absence of enforced randomness of selection. The report came out as a paper in Journal of the American Statistical Association and as a lengthy monograph; both were titled Statistical Problems of the Kinsey Report [28].

This experience surely led to new sampling methodology and to a better understanding of the usefulness and limitations of nonprobability and cluster-type samples. 


\subsection{Consulting.}

A consultant is a man who thinks with other people's brains.

Merck. Tukey's defense-related consulting has already been mentioned. In 1953 he began consulting at Merck, Sharp and Dohme on problems of biostatistics and continued to consult with them until his death. Prior to 1953 he had consulted with its predecessor, Merck, on problems arising in manufacturing.

Of John's work at Merck, J. Heyse wrote [44] that:

... he had a tremendous grasp of the obvious.

He further noted that John had worked on problems of statistical methods for safety assessment, clinical trials, laboratory quality control, health economics, clinical adverse experience evaluation, gene expression and microarray data. Tukey's publications include eight papers with Merck scientists.

On June 1, 2000 he visited Merck for a final time. The agenda of that visit included the topics "Use of TaqMan Assay for gene expression" and "Error models for microarray data" [44].

Researchers at Merck referred to the seat next to Tukey during the consulting meetings as "the batter's box."

Election Forecasting. Computers and election projection grew rapidly together, starting in 1952. That year Univac involved John Mauchly of ENIAC fame. The statistical projections based on partial returns triumphed. This was in contrast to the 1948 Dewey-Truman debacle and the failure of the 1936 Literary Digest poll.

In 1960 RCA/NBC hired CEIR, a statistical consulting firm, to develop a rapid projection procedure. CEIR consultants included Max Woodbury, Jack Moshman, Mauchly, Richard Scammon and JWT. That year Tukey won renown for preventing NBC from prematurely declaring Nixon the victor in the Presidential race.

Tukey took a data analysis approach to the problem of election projection, with the added spin that decisions had to be made very quickly. He has described the work as "the best education in real-time statistics that anybody could have" [12]. Data of several types were available: past history (at various levels, e.g., county), results of polls preceding the election, political scientists' predictions, partial county returns flowing in during the evening, and complete results for selected precincts. The data of the analyses were, in many cases, swings from sets of base values derived from past results and from political scientists' opinions. It turned out that the important problem of projecting turnout was more difficult than projecting candidate percentage. Starting with the 1962 Congressional election John assembled a statistical team to develop the required methodology and to analyze the results as they flowed in on election night. Early members of the 
team included Bob Abelson, Dick Link, John Mauchly, David Wallace, and myself.

Tukey sought "improved" estimates. His terminology was that the problem was one of "borrowing strength." Nowadays parts of the work would be described as shrinkage and empirical Bayes. Jargon was developed; for example, there were "barometric" and "swing-o-metric" precinct samples. The procedures developed can be described as an early example of empirical Bayes. The uncertainties, developed on a different basis, were just as important as the point estimates.

Tukey's attitude to release of the techniques developed is worth commenting on. On various occasions members of his "team" were asked to give talks and write papers describing the work. When Tukey's permission was sought, his remark was invariably that it was "too soon" and that the techniques were "proprietary" to RCA and NBC.

An illuminating incident took place the day President Kennedy was assassinated. The team was working at RCA's facility in Cherry Hill, NJ, on the forthcoming election of 1964. When the news came that President Kennedy had been killed, the meeting adjourned immediately. It was a long car ride back to Princeton. Tukey asked, "Do people want to talk?" He was invariably concerned with the feelings of others.

NBC stopped involving Tukey after the election of 1980. A stated reason was that exit polls, which interview people directly after they leave a polling station, had become highly refined. Such polls do have the advantage of being based on data from individual people who actually appeared to vote. This measurement device has the further flexibility that, if (because a race is close) there is a need for more data during the day more voters can be interviewed.

10. Editing and reviewing. Tukey was renowned for the amount of time that he spent and the detailed comments that he gave others, concerning their manuscripts. M. D. Godfrey wrote [40]:

I sent a draft of my Ph.D. thesis to John. John did two things, he read it and wrote comments in red all over it (and sent it back within a few weeks-about the luckiest thing that ever happened to me), and told Oskar (Morgenstern) about me. Thus, I went to Princeton.

Another example is that of Laurie Davies, who sent Tukey a copy of his paper "Data features" [30]. Tukey responded [103] with a 27-page detailed typescript built around sections titled: " $\mathrm{A}$ is for Approximations," " $\mathrm{B}$ is for Blandness," " $\mathrm{C}$ is for Challenges ...."

At the outset of his career John did a lot of work for Mathematical Reviews. He prepared some 123 reviews during the period 1940-1950. Many of these papers were written in languages other than English. His first review of a statistics paper appeared in 1946. Mathematical Reviews was then based at Brown University, and J. R. Tamarkin was one of the two first Editors. Possibly he remembered John from 
his undergraduate days. John reviewed books for JASA, Quart. Appl. Math., Ann. Math. Statist., Bull. AMS, Econometrica and J. Oper. Res. Soc.

Starting in the sixties John Tukey sought to bring order to the literature of statistics and probability by constructing indexes of the papers of those fields. As indicated he had done extensive work for Mathematical Reviews and prepared bibliographies before, for example, for time series, and perhaps this is what spurred him on. In particular he constructed a citation index. Re that effort it is impressive to see the roll call of eminent statisticians that JWT recruited to compile the papers and the reference lists. In particular he worked with J. Dolby, H. Resnikoff and I. C. Ross. The citation index that was constructed then was one of the earliest outside of the legal profession. JWT constructed other indices as well. These were taken over later by the American Mathematical Society and are part of MathSci.

Tukey prepared an in-depth and highly influential review of the literature of the uses of spectrum analysis in geophysics [84]. This paper also described various statistical methods for frequency analysis. Several times he prepared detailed time series bibliographies. These appeared in his papers or as dittoed preprints.

For the period 1950-1952 he was an Associate Editor of The Annals of Mathematical Statistics. Together with David Hoaglin and Fred Mosteller he edited and contributed to a sequence of books on contemporary data analysis, Understanding Robust and Exploratory Data Analysis (1983), Exploring Data Tables, Trends, and Shapes (1985), and Fundamentals of Exploratory Analysis of Variance (1991). He referred to the first two as "The Statistician's Guide to EDA" [45]. There is also the volume edited with S. Morgenthaler, Configural Polysampling: A Route to Practical Robustness (1991).

Tukey also prepared the index for Contributions to Mathematical Statistics, Wiley, New York (1950). This volume reprints R. A. Fisher's important articles.

\section{Visiting and traveling.}

The statisticians in the National Halothane Study met with him wherever he happened to be-Phoenix, Denver, Palo Alto-as he and Elizabeth drove across the country.

Mosteller [59]

JWT did a vast amount of traveling. The many, many journeys between Princeton and Washington stand out. There were also many trips to the West Coast and summer retreats to Grand Manon Island off New Brunswick, Canada, visits to Europe, Australia and New Zealand, and a cruise to Spitzbergen. He was a Fellow at the Center for Advanced Studies in Behavioral Science at Stanford in 19571958 and a Visitor to the Stanford Linear Accelerator (SLAC) in 1972 and 1979. He often went birding with Lincoln Moses and Bill Brown in California. He was an invited visitor to many universities and other institutions (e.g., the National Center for Atmospheric Research in 1979). 


\section{The later years.}

Research can and will go on; there will be a dawn tomorrow.

[97]

In 1985 JWT was quite emphatic that he was not retired-and he provided the evidence, beginning with his "Sunset salvo" [97]. At Princeton he had the titles of Donner Professor of Science Emeritus and Senior Research Statistician. He continued his consultancies and took on new ones, for example, at Bellcore and at Xerox PARC. At the latter a sequence of patents (including his name) related to information retrieval began to come out. These include:

1999 Method of ordering document clusters given some knowledge of user interests.

1998 Automatic method of identifying drop words in a document image without performing character recognition.

1998 Automatic method of generating thematic summaries from a document image without performing character recognition.

1998 Method and apparatus for information access employing overlapping clusters.

1998 Method of ordering document clusters without requiring knowledge of user interests.

1997 Method and apparatus for automatic document summarization.

1995 Detecting function words without converting a scanned document to character codes.

1995 Scatter-gather: A cluster-based method and apparatus for browsing large document collections.

1994 Iterative technique for phrase query formation and an information retrieval system employing same.

These show his continuing interest in finding relevant information, previously expressed in the Citation Index.

John continued as a Member of the Board of Fellows of Brown University and was on their Computer Committee until 1988. One change, though, was that he did seem to dress much more formally and often wore a Brown University necktie.

Right up until his death JWT continued to be a speaker (invariably the keynote) at conferences. He always had important things to say.

\section{JWT's style and attitude.}

\subsection{JWT and science.}

The stronger the qualitative understanding the data analyst can get of the subject matter field from which his data come, the better-just so long as he does not take it too seriously. 
... he always got to the science of the problem before he dealt with the statistics.

Heyse [44]

For him, white noise wasn't something you defined, it was something you observed.

Lome [53]

These quotations speak for themselves.

13.2. The work ethic. Tukey was a New Englander, a Yankee, someone who ate pie for breakfast, and this very much evidenced itself. It showed in his generosity, his patience, his dry humor, his patriotism and his working so incredibly hard. From personal experience I know that he was up early. There were the telephone calls, "I hope that I haven't woken you up." His thirst for problems was unquenchable.

He was not self-conscious in the matter of doing things differently, things like his labeling systems for a paper's sections, wearing khaki shorts, black polo shirts, pen holder in pocket ....

When I formally retire ... I do not plan to stop thinking or working. I plan to continue to provide both new techniques and new annoying-but-true statements.

\subsection{Helping others.}

... it was gratifying that John Tukey ... took an enduring interest in the efforts to put economic time series analysis on a modern basis.

Oskar Morgenstern in the Foreword to Granger and Hatanaka [42]

I have also discussed the subject with J. Tukey and H. Robbins, who helped break down my conviction that the usual procedure must be admissible.

Charles Stein [74] in his classic 1956 paper

Fortunately Tukey took an interest in the seismic project and conveyed his research ideas by mail.

E. Robinson [66]

John Seely Brown, ex-director of the Xerox Palo Alto Research Center (Xerox PARC), spoke of how Tukey "took him under his wing," providing "wisdom and encouragement" and "coaching and mentoring" [21].

Tukey had more than 105 coauthors. (The most joint works are with F. Mosteller.) He seemed happy for others to work through his ideas. He seemed to want the result, not the credit. Once I had an idea and told JWT. By the way he reacted I knew that he knew it. I said, "Oh, you knew that." John replied, "That's OK. Write it up." 
13.4. The style. He seemed to make an impression in all environmentsrestaurants, airports, stores, motels .... People knew he was special. One could tell just by looking at a document that it had been written by Tukey-the language, the punctuation, the handwriting, the section numbering, the new words and new uses for old (quite a few are listed in Appendix E) ....

most statisticians are used to winning arguments with subject-matter colleagues because they know BOTH statistics and the subject matter.

Tukey liked to argue points about his "business." He felt that was the "best way" to get the issues quickly onto the table. Of his "opponents" he remarked that $[3,34]$ :

... the person that I would be most careful with if they were in the audience and I was giving a paper was Milton Friedman.

Of Bayesian statistics he said [98]:

I believe that there are many classes of problems where Bayesian analyses are reasonable, mainly classes with which I have little acquaintance.

My personal impression is that his problem was not with Bayesian arguments per se; rather it was with some of the Bayesians. A somewhat related remark is that he liked to work with people he got along with. He permuted a number around on projects: Jim Dolby, Dave Hoaglin, Lyle Jones, John Gilbert, Stefan Morgenthaler, Lincoln Moses, Fred Mosteller, myself [60, 5]. Some persons had great faith in Tukey's judgment on things far from statistics. F. Mosteller wrote this of his wife Virginia, who had known Tukey since FCRO days [60].

Concerning Tukey's amusements, Elizabeth said, "He reads mystery stories at night to go to sleep" and she also said that he is "always, always playing classical music loudly," the last to JWT's surprise [35]. Tukey was famous for finding stores that sold secondhand mystery, adventure and science fiction paperbacks and was a serious collector. He also completed crossword books and worked double crostics. Early in his career he was an avid photographer and enthused others [70].

Tukey was a great lover of birds and the sea frequenting Brigantine NWR near Atlantic City. He owned a catamaran, concerning which there is a story later.

\section{His family.}

\subsection{Elizabeth Rapp Tukey.}

One is so much less than two.

JWT's eulogy following Elizabeth's death [6]

Elizabeth was born March 2, 1920 in Ocean City, New Jersey. She was absolutely basic to John's life from when they met and until her death on January 6, 
1998. One simply had to be with either of them to know this. Elizabeth was ill for several years at the end. John cooked for her and dutifully nursed her until he became too tired at which point a care provider was hired.

Elizabeth went to Temple University and was valedictorian in the 1944 class in Business Administration at Radcliffe College. When she and John met, she was Personnel Director at Educational Testing Service, Princeton, N. J. They met at a folk dance class in 1949, John being one of the instructors. Elizabeth told me that she had seen him previously at a talk on campus and had particularly noticed his putting difficult questions to the speaker.

Elizabeth and John married July 19, 1950. John looks so proud in the wedding photo [35]. To quote Fred Mosteller [59], "John's mother, a no-nonsense lady, finally got her wish that he marry a real nice girl." They had no children, but doted on their Anscombe nephews and niece. They also had a large extended family via students.

The Tukey's home in Princeton, on Arreton Road, was designed by the renowned architect R. W. Bauhan. It was exceedingly well furnished, for Elizabeth collected 18th and 19th century American furniture. Later she was a dealer. Her treasures were disposed of in a major sale in 2000 [72]. The Tukeys also had a second house on the water in Westport Point, Mass., an old whaling town. It has a plaque dating it to 1785. Elizabeth was First Chair of the Princeton Township Historic Preservation Commission and set out to protect the historic sites near Princeton.

In later years Elizabeth attended many of John's conferences, typically sitting in the front row and sometimes commenting. She was always available for the students, always caring, always remembering personal details. Once when one of the students called and asked to speak to the "the great man," Elizabeth's remark was "There is no great man here. We are ordinary people."

Elizabeth participated in several interviews $[35,39]$ and she wrote a speech for JWT's 80th birthday celebration [77]. There is also a memorial volume prepared by her sister, Phyllis Anscombe [6]. One of Elizabeth's remarks tells part of the story behind JWT's contributions:

As the wife of another dedicated workaholic I understand the selfless love and devotion, accommodation and deprivation required to "keep them on the road."

Elizabeth to Frances Baker [77]

14.2. Parents. John's parents had graduated first and second in the Bates College class of 1898, but did not marry until 1912. Ralph Tukey earned a second B.A. at Harvard en route to an M.A. there. In 1906, he obtained a Ph.D. in Latin from Yale University. He taught at Hopkins Grammar School in New Haven and after the marriage at William Jewell College, near Kansas City, leaving in about 1920. Thereafter he taught at New Bedford High School and ran the Latin Department, and at times other departments. Tukey's mother was a substitute 
teacher there and very active in the YWCA. As mentioned earlier, being married, she was not allowed to hold a permanent position.

Tukey set up a scholarship at Bates College in their honor. The precise wording of the terms is notable:

The recipient to be selected from the upper two percent of his or her class in academic standing, based upon the scholastic records of the class at the end of the first five semesters of undergraduate study, with first preference for demonstrated scholastic excellence in mathematics or the classics or some other field of academic study in the natural sciences.

One wonders whether Bates has a special computer program to identify the winner.

14.3. The rest of the family. As hinted above, Elizabeth's sister, Phyllis Rapp, also married a scientist and statistician, Frank Anscombe. Phyllis and Frank had met through Elizabeth and John. John referred to Frank as his brother-in-squaredlaw. In later years, when Frank and John were asked what they did, one of their replies was "We marry Rapp daughters." This story and others may be found in the memorial volume that Phyllis prepared [6]. The Anscombes provided the Tukeys with three nephews and a niece.

Anscombe joined the Princeton faculty in 1956. When Tukey recommended the appointment he wrote his Mathematics colleagues that he "wanted someone to talk to, not at." John and Frank wrote some papers together, for example, the much quoted [4] on analysis of residuals. They were also discussants of each other's work on occasion. But because Frank was a Bayesian and John was not, there were surely lots of family "discussions" of statistics. Having left for Yale in 1963 Anscombe wrote a book [2], in the Preface of which he writes that it is "a festivity in ... honor" of J. W. Tukey and K. E. Iverson. Anscombe died October 17, 2001.

John had two first cousins Clayton and Wilder Tasher whom he was close to. He also collaborated with fifth cousin Paul Tukey, whom he met when the latter was a Princeton undergraduate. They wrote four papers together, principally on graphics.

15. Some stories. There are many JWT stories. Here are a few.

1. In 1961 the Tukeys had a Come as Your Spouse Party. We all dressed up except for Gina and Sam Wilks. There may even have been a contest for the "best dressed." Later that year I went to the University of Michigan to give a talk. When I told Jimmy Savage, then a Professor at Michigan, about the party, his remark was, "I know too much Freud to do something like that."

2. Jimmie Savage once told F. R. Anscombe's parents that if you ask John how to milk an elephant, he will think you are teasing him and not tell you. But if you just chat with him, in due course, he may just happen of his own accord to get around to telling you how to milk an elephant.

3. When on sabbatical in New Zealand 25 years ago this writer learned the following method to go between the centigrade and Fahrenheit scales of 
temperature in a couple of important cases-one simply reverses the digits of 61 and 16 and of 82 and 28. I told this to John and he very quickly came up with another case. He remarked that 40 converts to 04 .

4. Tukey was known for his vehicles. He had a 1936 wood-paneled station wagon for a number of years. Once when he was driving down Nassau Street, the passenger door fell off. A manuscript of loose pages on the passenger seat fell out and blew around. JWT had to chase the many pink pages all about the street. He later had a blackish truck, "The Monster," and still later a Mustang convertible.

5. To a student who described a possible thesis topic JWT is said to have remarked: "I can see that you have a complex problem: it has a real and an imaginary part."

6. The way that JWT dressed has already been referred to. This clearly made him stand out at meetings at the AT\&T head office. One story is that at a meeting there he was lying on the floor using a wastepaper basket as a pillow, and at one point his head was actually in the basket. When he spoke, his voice boomed out. (As mentioned earlier, he sometimes referred to himself as a "horizontal consultant.”)

7. If JWT needed graph paper, say at a consulting session, he simply overlaid lined papers at right angles. He also advised that, when one had a piece of an unusual graph paper, one shouldn't plot on it, rather on a piece of tracing paper on top. In the 1960s and 1970s he had a $t$-table that he carried in his wallet. In another period he traveled with a succession of HP calculators.

8. Revelations, Chapter 13, Verse 18 is the last line of the text of the EDA book [90]. It is on page 666 . The verse is:

Here is wisdom. Let him that hath understanding count the number of the beast; for it is the number of a man; and his number is six hundred threescore and six.

9. After coming back from a European trip, the Brillingers had the Tukeys and some others over for dinner. Being young, the Brillingers offered to show the slides of their trip. Being polite the guests did not object. During the show JWT was steadily making incisive/informative remarks. At a certain point, though, his remarks stopped. After 10-15 minutes they resumed. Elizabeth said: "Now John Tukey, don't you pretend that you haven't been asleep." After a bit of pause, John: "Well if Lorie hadn't made me such a good dinner, I wouldn't have fallen asleep."

10. Once I visited Bell Labs from London, driving to Murray Hill from Leonia via the Garden State Parkway. At one of the toll booths I picked up a map to learn the exit for Murray Hill and noticed that the back was a Send Help sign. At the Labs I went to visit W. H. Williams. The two of us put the map up on Bill's door, 
which was swung out into the hallway. In a couple of minutes JWT appeared in the office, asking what the problem was.

11. JWT had been fairly hefty earlier in his life. He took to dieting, eating prunes for example. He would pass the box of prunes around at meetings for all to share. Those taking up the offer were then left to wonder what to do with the prune pit.

On one occasion when I was over at the Tukey house, John took one of those small personal fruit pies out of the fridge. He cut himself a wedge of the usual shape, put it on a plate, and ate it in one gulp. (JWT was known for loving mince and apple pies.)

12. JWT kept his notes and particularly transparencies in refrigerator bags. He also was an early user of multi-colored transparencies and of two overhead projectors. Once, when Peter Bloomfield and I were using some of JWT's transparencies in a short course, JWT complained that we were giving away the punch lines because we were simply showing the whole transparency at the outset. Tukey always covered his view graphs, then moved down the page so that you could read only what he was talking about.

JWT tracked down special transparencies and "tools," especially an eraser for changing slides done in permanent marker. One of his papers [92] gives details of grade and thickness.

13. Once JWT and his cousin Paul were giving a team presentation. They each had two overheads! F. R. Anscombe describes the situation as "twice double Tukey."

14. A lot of the work and learning at the Labs occurred at the lunch table. Martin Wilk and Ram Gnanadesikan, among others, launched the idea of forming a Society of Data Analysis. A suggestion was that JWT would be SODA Pop. (Gnanadesikan tells the story that JWT came up with the name "data analysis" at a party at the Brillinger house.)

15. In the early sixties there was once a very heavy snowfall in Princeton. It was not possible to drive, but John was so concerned about the birds having food that he walked out some distance to purchase and carry home a large sack of birdseed.

16. Mosteller writes [60] that, when he submitted a draft of his thesis, the Mathematics Department said that they were in the business of theorems and where were his. Tukey laughed at the criticism saying, "We've got lots of theorems; let's give them a good one." And they did.

17. Tukey took his nephew Anthony sailing once. They sailed out under the Westport bridge, but got trapped outside because the tide had come in. Tukey heeled the boat over and walked along a ledge under the bridge holding the tip 
of the mast to deal with the situation. His remark to Anthony was, "Your aunt doesn't need to know about this."

I can vouch only for the personal stories above, and my memory may have played some tricks, but there are lots of good Tukey stories.

16. The collected works. Many of Tukey's published papers, as well as a number of previously unpublished works (e.g., The Problem of Multiple Comparisons), appear in The Collected Works of John W. Tukey (henceforth CWJT), first published by Wadsworth, and more recently by CRC Press. CWJT was Bill Cleveland's wonderful prescient idea. Each volume has forewords by JWT and its editor, discussing various of the individual papers.

The volumes are:

I, II. Time Series (1984-85) (D. R. Brillinger, ed.).

III, IV. Philosophy and Principles of Data Analysis (1986) (L. V. Jones, ed.).

V. Graphics (1988) (W. S. Cleveland, ed.).

VI. More Mathematical (1990) (C. L. Mallows, ed.).

VII. Factorial and ANOVA (1992) (D. R. Cox, ed.).

VIII. Multiple Comparisons (1994) (H. I. Braun, ed.).

Of course, as the dates show, these are hardly the complete works; many earlier items are missing and Tukey kept right on working to the end.

A partially complete vitae, a list of coauthors and a bibliography of his works is in [19]. Bell Labs has a web site containing a variety of materials related to John, including a bibliography and personal reminiscences $(\mathrm{cm}$.belllabs.com/cm/ms/departments/sia/tukey). An oral history of the early years of mathematics at Princeton University is on the Mathematics Department's web site, www.princeton.edu/mudd/math. One interview is with JWT, others mention him.

Papers by Tukey and co-authors are still appearing, so the bibliography is not yet complete. Tukey's personal papers, a massive collection, have been given to the American Philosophical Society (APS). This is the largest gift of papers that the APS has received. David Hoaglin is his literary executor, in support to co-executors Anthony and Frank R. Anscombe.

17. Discussion. Many scientists become more applied as they age. It can be a simple result of the fact that today's theory becomes tomorrow's practice. JWT's mathematics background and talent remained. He continually abstractedfrom specific scientific problems and data sets to creating general principles and methods. The point of point set topology became the datum of statistics, the injection became the running median or smooth. For a schematic of his approach see Figure 1 in [18]. 
18. Epilogue. John Tukey was a giant of a scientist and public servant. He was an academic who liked to argue and expected to win. But at the same time he was the most generous, patient, caring soul. It was a privilege to know John Tukey. Every conversation or sighting was an adventure.

I end with a personal story. When my elder son died after a twenty-year struggle with a brain tumor and John heard of his death, he telephoned. John was weeping away.

\section{APPENDIX A. TIMELINE}

1915 Born, New Bedford, MA, June 16.

1933 Entered Brown University.

1936 B.Sc. (Chemistry), Brown.

1937 M.Sc. (Chemistry), Brown.

1938 M.A. (Mathematics), Princeton.

1939 Ph.D. (Mathematics), Princeton.

1939-1941 H. B. Fine Instructor of Mathematics, Princeton.

1941-1948 Assistant Professor of Mathematics, Princeton.

1941-1945 Research Associate, Fire Control Research Office, Princeton.

1942-1944 Technical Expert, Frankford Arsenal, Philadelphia.

1945-1985 Member of Technical Staff, AT\&T Bell Laboratories.

1948-1950 Associate Professor of Mathematics, Princeton.

1950 Marriage to Elizabeth L. Rapp.

1950-1966 Professor of Mathematics, Princeton.

1955-1957 Vice President, American Statistical Association.

1958-1961 Assistant Director of Research, Communications Principles, AT\&T

Bell Laboratories.

1960-1963 President's Science Advisory Committee.

1960-1961 President, Institute of Mathematical Statistics.

1961-1964 Science Information Council, NSF.

1961-1985 Associate Executive Director, Research-Information Sciences, AT\&T

Bell Laboratories.

1966 Princeton Statistics Department created.

1966-1985 Professor of Statistics, Princeton.

1970 Statistics Undergraduate Major started at Princeton.

1974-1988 Board of Fellows, Brown University.

1975-1977 Vice President, American Philosophical Society.

1976-1985 Donner Chair of Science, Princeton.

1980-2000 Member, Advisory Committee on Special Projects, Center for Advanced Study in the Behavioral Sciences, Stanford, CA.

1985 Retired (end of June), aged 70.

1985-2000 Senior Research Statistician, Princeton. 
1994-1998 Senior Advisor to Task Force on Statistical Inference, American Psychological Association.

2000 Died, New Brunswick, New Jersey, July 26.

\section{APPENDIX B. SOME ACADEMIC HONORS}

1938-1939 Jacobus Fellowship, Princeton University. 1949-1950 Guggenheim Fellow.

1958 Wald Lecturer, IMS, "The mathematical foundations of fiducial inference."

1961 Member, National Academy of Sciences.

1962 Member, American Philosophical Society.

1964 Member, American Academy of Arts and Sciences.

1965 S. S. Wilks Medal, ASA, "... for his contributions to the theory of statistical inference, his development of procedures for analyzing data, and his influence on applications of statistics in many fields."

1956 Statistician of the Year, ASA Chicago Chapter.

1967 Fisher Lecturer, "Some perspectives on data analysis."

1973 National Medal of Science, "For his studies in mathematical and theoretical statistics, and for his outstanding contributions to the applications of statistics to the physical, social and engineering sciences."

1975 Hitchcock Lecturer, University of California, Berkeley.

1975 Scott Lecturer, Cambridge University, England.

1977 Shewhart Medal, American Society for Quality Control.

1982 Medal of Honor of the IEEE, "For his contributions to the spectral analysis of random processes and the fast Fourier transform algorithm."

1982-1983 Deming Medal, American Society for Quality Control.

1984 James Madison Medal, Princeton University.

1985 John von Neumann Lecturer, SIAM.

1991 Foreign Member, Royal Society of London.

1989 Monie A. Ferst Award, Sigma Xi.

1990 ETS Service Award, "Distinguished service to measurement."

1999 M. Zelen Leadership Award, Harvard University.

\section{HONORARY DOCTORATES}

1962 Case Institute of Technology.

1965 Brown University.

1968 Yale University.

1969 University of Chicago.

1978 Temple University.

1998 Princeton University.

1999 University of Waterloo. 
APPENDIX C. PH.D. STUDENTS

Frederick Mosteller, 1946

John Walsh, 1947

Donald Fraser, 1948

Melvin Peisakoff, 1950

Leo Goodman, 1950

Bernard Sherman, 1950

Ray Murphy, 1951

Paul Meier, 1951

Alan James, 1953

David Wallace, 1953

Marvin Minsky, 1954

Richard Link, 1954

Ralph Wormleighton, 1955

Arthur Dempster, 1956

Thomas Kurtz, 1956

N. Roy Goodman, 1957

Bradley Bucher, 1957

James Templeton, 1957

Harvey Arnold, 1958

David Brillinger, 1961

Donald Burdick, 1961

John Hartigan, 1962

Peter Nemenyi, 1963

Thomas Wonnacott, 1963

James Thompson, 1965

Morton Brown, 1965

W. Morven Gentleman, 1966

James Filliben, 1969
Charles Lewis, 1970

Stanislaus D'Souza, 1971

Helge Knudsen, 1971

James Schlesselman, 1971

David Hoaglin, 1971

Alan Gross, 1973

Anita Nowlin, 1973

Edward Binkowski, 1974

Steven Finch, 1974

Lincoln Polissar, 1974

Paul Velleman, 1976

Tony Quon, 1976

Susan Arthur, 1979

Michael Schwarzschild, 1979

Karen Kafadar, 1979

Roberta Guarino, 1981

Katherine Krystinik, 1981

Paul Horn, 1981

Stephan Morgenthaler, 1983

Fanny O'Brien, 1984

Dhammika Amaratunga, 1984

Clifford Hurvich, 1985

George Easton, 1985

Ha Nguyen, 1986

David Brown, 1987

Katherine Hansen, 1988

Eugene Johnson, 1988

\section{APPENDIX D. SOME JWT WORDS (WITH NEW MEANINGS) AND PHRASES}

alanysis

alias (in time series)

ANOVA

badmandments

bagplot

batch

bispectrum

bit biweight

bland distribution

borrowing strength

boxplot

cepstrum

coco

complex demodulation

confirmatory data analysis (CDA) 
darius

data analysis

dedomulation

deficiency

depth

dyadic ANOVA

exploratory data analysis (EDA)

faceless value

family of covers

fences

5-number summary

flogs

froots

finite character

Garden of Eden

hamming

(hanging) rootogram

hanning

hat matrix, $H$

hinge

Huberizing

jackknife

linear programming

midmean

multihaver

Munkery

polyefficiency

polykay

polysampling polyspectrum

prewhitening

quefrency

RadGaussianization

rahmonic

regressogram

reroughing

rootogram

rough

running median

saphe cracking

schematic plots

slash distribution

smear-and-sweep

smelting

smoothing and decimation

software (first in print)

stem-and-leaf

tapering

toolglass

trimming

twicing

vacuum cleaner

vague concept

window carpentry

winsorizing

Winsor's principle

Zorn's Lemma

\section{APPENDIX E. SOME SAYINGS}

"One can Fourier transform anything-often meaningfully."

"You don't take the stamp off the envelope, you take the envelope off the stamp."

"You can't expect scientists to solve political problems."

"Axiom 1: People are different."

“...maps lie, lie, lie."

"Avoid one word with too many meanings."

"It is good to choose coefficients to magnify the signal, but it is far better to choose them to cancel out the noise."

"Statistical philosophy, beware logical detail." 
"Principle of Parsimony. It may pay not to try to describe in the analysis the complexities that are really present in the situation."

"More lives have been lost looking at the raw periodogram than by any other action involving time series!"

"Everyone thinks that the data in other people's subjects are in better shape."

"Have you ever seen a spherical milk bottle?"

"Finding the question is often more important than finding the answer."

"Life is like a double-crostic; we can do far more than we know."

"Time is connected."

"The test of a good procedure is how well it works, not how well it is understood."

"The purpose of asymptotic theory in statistics is simple: to provide usable approximations before passage to the limit."

"Real data has ends!"

"An argument of statisticians."

"efficiency $=$ statistical efficiency $\times$ usage."

Acknowledgments My remarks are necessarily personal, but I have built on other people's work, for example, [3, 34, 35]. Simple things like the indexing system that was set up for Tukey's papers helped immensely. In particular I wish to thank: F. R. Anscombe, W. O. Baker, H. Boas, B. Bolt, A. Bowker, J. S. Brown, A. W. Burks, W. Cleveland, N. Chomsky, W. Eddy, L. Fernholz, S. Fienberg, D. H. Fremlin, E. Garfield, D. Gauld, R. Gnanadesikan, M. Godfrey, I. J. Good, L. Goodman, J. Heyse, N. R. Howse, K. Kafadar, L. V. Jones, L. Lome, H. V. McIntosh, C. Mallows, E. Michael, F. Mosteller, E. Parzen, S. Morgenthaler, H. Pohlmann, F. Smithies, G. Tee, D. Temple-Lang, R. Waller, the Editor and the referees.

Michael Godfrey gave me help throughout. David Hoaglin gave a very careful reading of the penultimate draft. Tukey's eldest nephew F. R. Anscombe's presence is everywhere in this article. In particular, he gave me access to some of the writings going to the APS.

\section{REFERENCES}

[1] Andrews, D. F., Bickel, P. J., Hampel, F. R., Huber, P. J., Rogers, W. H. and TUKEY, J. W. (1972). Robust Estimates of Location: Survey and Advances. Princeton Univ. Press.

[2] Anscombe, F. J. (1981). Computing in Statistical Science Through APL. Springer, New York.

[3] Anscombe, F. J. (1988). Frederick Mosteller and John W. Tukey: A conversation. Statist. Sci. 3 136-144.

[4] Anscombe, F. J. and Tukey, J. W. (1963). The examination and analysis of residuals. Technometrics 5 141-160.

[5] Anscombe, F. R. (2002). Personal communication.

[6] Anscombe, P. R. (1999). Memories of Betty Lou. Private publication. New Haven, CT.

[7] Aspray, W. and Tucker, A. (1985). Interview of John Tukey. The Princeton Mathematics Community in the 1930s. Transcript Number 41 (PMC41), Princeton Univ. 
[8] Aspray, W. and Tucker, A. (1985). Interview of Robert E. Greenwood. The Princeton Mathematics Community in the 1930s. Transcript Number 16 (PMC16), Princeton Univ.

[9] Atal, B. S., Chang, J.-J., Mathews, M. V. and Tukey, J. W. (1978). Inversion of articulatory-to-acoustic transformation in the vocal tract by a computer-sorting technique. Journal of the Acoustical Society of America 63 1535-1555.

[10] BAKER, W. O. (2002). Personal communication.

[11] Basford, K. E. and Tukey, J. W. (1998). Graphical Analysis of Multiresponse Data. Chapman and Hall, London.

[12] Bell Labs News (1985) 25 (18).

[13] Blackman, R. B. and Tukey, J. W. (1959). The Measurement of Power Spectra from the Point of View of Communications Engineering. Dover, New York. [Also Bell System Tech. J. 37 (1958) 185-282, 485-569.]

[14] Bloomfield, P., Brillinger, D. R., Cleveland, W. S. and Tukey, J. W. (1979). The Practice of Spectrum Analysis. Short course offered by University Associates, Princeton.

[15] Bode, H. W., Mosteller, F., Tukey, J. W. and Winsor, C. P. (1949). The education of a scientific generalist. Science 109 553-558.

[16] Bogert, B. P., Healy, M. J. R. and Tukey, J. W. (1963). The quefrency alanysis of time series for echoes: cepstrum, pseudo-autocovariance, cross-cepstrum and saphe-cracking. In Proceedings of the Symposium on Time Series Analysis (M. Rosenblatt, ed.) 209-243. Wiley, New York.

[17] Bolt, B. (2001). Personal communication.

[18] Brillinger, D. R. (2002). John W. Tukey's work on time series and spectrum analysis. Ann. Statist. 30 1595-1618.

[19] Brillinger, D. R., Fernholz, L. T. and Morgenthaler, S., eds. (1997). The Practice of Data Analysis. Princeton Univ. Press.

[20] Brillinger, D. R., Jones, L. V. and Tukey, J. W. (1978). The Management of Weather Resources II: The Role of Statistics in Weather Resources Management. U.S. Government Printing Office, Washington, DC.

[21] BRown, J. S. (2002). Personal communication.

[22] Burks, A. W. (2000). Personal communication.

[23] Burks, A. W., Goldstine, H. H. and von Neumann, J. (1947). Preliminary discussion of the logical design of an electronic computing instrument. In Papers of John von Neumann on Computing and Computer Theory (W. Aspray and A. Burks, eds.) (1987) 17-82. MIT Press.

[24] Burrows, W. E. (1986). Deep Black: Space Espionage and National Security. Random House, New York.

[25] Canby, E. T. (1980). Audio, December 8-9.

[26] CASEY, W. J. (1983). Letter dated 17 October 1983 in Tukey Archives at the American Philosophical Society.

[27] Census Trial (1992). The census trial. Available at http://home.stat.ucla.edu/census.

[28] Cochran, W. G., Mosteller, F. and Tukey, J. W. (1954). Statistical Problems of the Kinsey Report on Sexual Behavior in the Human Male. Amer. Statist. Assoc., Washington.

[29] Cooley, J. W. (1992). How the FFT gained acceptance. IEEE Signal Processing Magazine 9 10-13.

[30] Davies, P. L. (1995). Data features. Statist. Neerlandica 49 185-245.

[31] Dolby, J. L. and Tukey, J. W. (1973). Index to Statistics and Probability. The Statistics CumIndex 1. R and D Press, Los Altos, CA.

[32] Ericksen, E. P., KadAne, J. B. and Tukey, J. W. (1989). Adjusting the 1980 Census of population and housing. J. Amer. Statist. Assoc. 84 927-944. 
[33] Fagan, M. D. (1978). A History of Engineering and Science in the Bell System: National Service in War and Peace (1925-1975). Bell Telephone Laboratories, New York.

[34] Fernholz, L. T. and Morgenthaler, S. (1997). A conversation with John W. Tukey. In The Practice of Data Analysis (D. R. Brillinger, L. T. Fernholz and S. Morgenthaler, eds.) 26-45. Princeton Univ. Press.

[35] Fernholz, L. T. and Morgenthaler, S. (2000). A conversation with John W. Tukey and Elizabeth Tukey. Statist. Sci. 15 79-94.

[36] Feynman, R. P. (1999). The Pleasure of Finding Things Out. Perseus, Cambridge, MA.

[37] Fremlin, D. H. (2001). Personal communication.

[38] Gleick, J. (1992). Genius: The Life and Science of Richard Feynman. Pantheon, New York.

[39] Gnanadesikan, R. and Hoaglin, D. C. (1993). A Discussion with Elizabeth and John Tukey. Video tape. Parts I and II. Amer. Statist. Assoc., Alexandria, VA.

[40] Godfrey, M. D. (2001). Personal communication.

[41] GOOD, I. J. (2002). Personal communication.

[42] Granger, C. W. J. and Hatanaka, M. (1964). Spectral Analysis of Economic Time Series. Princeton Univ. Press.

[43] Halmos, P. R. (1988). Some books of auld lang syne. In A Century of Mathematics in America, Part I (P. Duren, ed.) 131-174. Amer. Math. Soc., Providence, RI.

[44] Heyse, J. (2001). Personal communication.

[45] HoAglin, D. C. (2002). Personal communication.

[46] Howes, N. R. (1995). Modern Analysis and Topology. Springer, New York.

[47] Howes, N. R. (2000). Personal communication.

[48] Isbell, J. R. (1964). Uniform Spaces. Amer. Math. Soc., Providence, RI.

[49] Jones, J. H. (1997). Alfred C. Kinsey. Norton, New York.

[50] Jones, L. V. (1996). A history of the National Assessment of Educational Progress and some questions about its future. Educational Researcher 25 15-22.

[51] KAFADAR, K. (2001). Personal communication.

[52] Kendall, M. G. and Stuart, A. (1958). The Advanced Theory of Statistics 1. Griffin, London.

[53] Lome, L. (2002). Personal communication.

[54] Lowrance, W. W. (1985). Modern Science and Human Values. Oxford Univ. Press.

[55] MaC Lane, S. (1989). The Applied Mathematics Group at Columbia in World War II. In A Century of Mathematics in America, Part III (P. Duren, ed.) 495-515. Amer. Math. Soc., Providence, RI.

[56] Mallows, C. M. and Tukey, J. W. (1982). An overview of techniques of data analysis, emphasizing its exploratory aspects. In Some Recent Advances in Statistics (J. Tiago de Oliveira and B. Epstein, eds.) 111-172. Academic Press, London.

[57] Menra, J. (1994). The Beat of a Different Drum: The Life and Science of Richard Feynman. Oxford Univ. Press.

[58] Mood, A. M. (1984). Conversation between G. W. Brown and A. M. Mood. The Princeton Mathematics Community in the 1930s. Transcript Number 3 (PMC3), Princeton Univ.

[59] Mosteller, F. (1984). Biography of John W. Tukey. In The Collected Works of John W. Tukey I. Time Series: 1949-1964 xv-xvii. Wadsworth, Belmont, CA.

[60] Mosteller, F. (2001). Personal communication.

[61] Mosteller, F. and Tukey, J. W. (1977). Data Analysis and Regression: A Second Course in Statistics. Addison-Wesley, Reading, MA.

[62] PÉtARD, H. (1938). A contribution to the mathematical theory of big game hunting. Amer. Math. Monthly 45 446-447.

[63] Pierce, J. R., Shannon, C. E. and Tukey, J. W. (1948). Cathode ray device. U.S. Patent No. $2,576,040$. 
[64] Polmar, N. (2001). Spyplane: The U-2 History Declassified. MBI, Osceola, WI.

[65] Princeton University News Release (2000). July 26.

[66] Robinson, E. A. (1982). A historical perspective of spectrum estimation. Proc. IEEE 70 885-907.

[67] Ross, I. C. and Tukey, J. W. (1973). Index to Statistics and Probability: Locations and Authors 5. R and D Press, Los Altos, CA.

[68] Ross, I. C. and Tukey, J. W. (1975). Index to Statistics and Probability: Permuted Titles. A-Microbiology, Microclimatic-Z 3, 4. R and D Press, Los Altos, CA.

[69] SCHEFFÉ, H. and TUKEY, J. W. (1944). A formula for sample sizes for population tolerance limits. Ann. Math. Statist. 15217.

[70] Smithies, F. (1995). Reminiscences of Ralph Boas. In Lion Hunting and Other Mathematical Pursuits (G. L. Alexanderson and D. H. Mugler, eds.) 25-31. Math. Assoc. Amer., Washington.

[71] Smithies, F. (2002). Personal communication.

[72] Solis-Cohen, L. (2000). Freeman's Tukey sale. Maine Antique Digest. June.

[73] Spitzer, L. (1997). Dreams, Stars, and Electrons: Selected Writings of Lyman Spitzer, Jr. (L. Spitzer, Jr. and J. P. Ostriker, eds.). Princeton Univ. Press.

[74] STEIN, C. (1956). Inadmissibility of the usual estimator for the mean of a multivariate normal distribution. Proc. Third Berkeley Symp. Math. Statist. Probab. 1 197-206. Univ. California Press, Berkeley.

[75] Tucker, A. (1985). Career, Part 2. The Princeton Mathematics Community in the 1930s. Transcript Number 39 (PMC39), Princeton Univ.

[76] Tucker, A. (1985). Interview of Merrill Flood. The Princeton Mathematics Community in the 1930s. Transcript Number 11 (PMC11), Princeton Univ.

[77] Tukey, E. R. (1997). Speech at JWT's 80th birthday celebration. In The Practice of Data Analysis (D. R. Brillinger, L. T. Fernholz and S. Morgenthaler, eds.) 46-47. Princeton Univ. Press.

[78] Tukey, J. W. (1940). Convergence and Uniformity in Topology. Princeton Univ. Press.

[79] Tukey, J. W. (1953). The growth of experimental design in a research laboratory. In Research Operations in Industry 303-313. King's Crown Press, New York.

[80] TUKEY, J. W. (1959). Equalization and pulse shaping techniques applied to the determination of initial sense of Rayleigh waves. In The Need for Fundamental Research in Sesimology 60-129, Appendix 9. U.S. Dept. of State, Washington.

[81] TukeY, J. W. (1963). Mathematics 596: An introduction to the frequency analysis of time series. In The Collected Works of John W. Tukey I. Time Series: 1949-1964 503-650. Wadsworth, Belmont, CA.

[82] Tukey, J. W. (1964). Samuel Stanley Wilks. Yearbook of the American Philosophical Society 147-154. Amer. Philos. Soc., Philadelphia.

[83] Tukey, J. W. (1965). Mathematics. In Listen to Leaders in Science (A. Love ed.) 217-232. Tupper and Love, Atlanta.

[84] Tukey, J. W. (1966). Use of numerical spectrum analysis in geophysics. Bull. Internat. Inst. Statist. 41 267-307.

[85] Tukey, J. W. (1967). What can mathematicians do for the Federal Government? Amer. Math. Monthly 74(1, Part II) 101-109.

[86] TuKey, J. W. (1967). What have statisticians been forgetting? In The Collected Works of John W. Tukey IV. Philosophy and Principles of Data Analysis: 1985-1986 587-599. Wadsworth, Monterey, CA.

[87] Tukey, J. W. (1972). Data analysis, computation and mathematics. Quart. Appl. Math. 30 $51-65$. 
[88] Tukey, J. W. (1973). Lags in statistical technology. In Proceedings of the First Canadian Conference in Applied Statistics (C. S. Carter, T. D. Dwividi, I. P. Fellegi, D. A. S. Fraser, J. P. McGregor and D. A. Sprott, eds.) 96-104. Amer. Statist. Assoc., Washington.

[89] Tukey, J. W. (1973). Index to Statistics and Probability: Citation Index 2. R and D Press, Los Altos, CA.

[90] Tukey, J. W. (1977). Exploratory Data Analysis. Addison-Wesley, Reading, MA.

[91] Tukey, J. W. (1978). Statistics at Princeton. In A Princeton Companion (A. Leitch, ed.) 449451. Princeton Univ. Press.

[92] Tukey, J. W. (1982). Another look at the future. In Computer Science and Statistics: Proc. 14th Symposium on the Interface (K. W. Heiner, R. S. Sacher and J. W. Wilkinson, eds.) 2-8. Springer, New York.

[93] Tukey, J. W. (1982). Discussion of "The role of statistical graduate training." In Teaching of Statistics and Statistical Consulting (J. S. Rustagi and D. A. Wolfe, eds.) 379-389. Academic Press, New York.

[94] Tukey, J. W. (1984). The Collected Works of John W. Tukey I. Time Series: 1949-1964. Wadsworth, Belmont, CA.

[95] TukeY, J. W. (1984). Speech when receiving James Madison Medal, Princeton Univ.

[96] Tukey, J. W. (1985). Comment on "Estimating the population in a census year: 1980 and beyond," by E. P. Ericksen and J. B. Kadane. J. Amer. Statist. Assoc. 80 127-128.

[97] Tukey, J. W. (1986). Sunset salvo. Amer. Statist. 40 72-76.

[98] Tukey, J. W. (1986). The Collected Works of John W. Tukey III. Multiple Comparisons: 19481983. Wadsworth, Belmont, CA.

[99] TukeY, J. W. (1990). The Collected Works of John W. Tukey IV. More Mathematical: 1938 1984. xlvii-1. Wadsworth, Monterey, CA.

[100] TUKeY, J. W. (1990) (with others). Proposed guidelines for statistical adjustment of the 1990 Census. Hearing before the Subcommittee on Census and Population of the Committee on Post Office and Civil Service. House of Representatives. Serial No. 101-43. U.S. Government Printing Office, Washington.

[101] Tukey, J. W. (1990) (with others). Census coverage evaluations. Hearing before the Subcommittee on Census and Population of the Committee on Post Office and Civil Service. House of Representatives. Serial No. 101-79. U.S. Government Printing Office, Washington, DC.

[102] TUKEY, J. W. (1992). Discussion of "Jackknife-after-bootstrap standard errors and influence functions," by B. Efron. J. Roy. Statist. Soc. Ser. B 54 120-121.

[103] TuKEY, J. W. (1995). Issues relevant to an honest account of data-based inference, partially in the light of Laurie Davies' paper. Preprint, Princeton Univ.

[104] Tukey, J. W. (1997). Report to the Special Master. In Report to the New Jersey Supreme Court, by R. S. Cohen.

[105] WeIsburd, D. (1997). Good for what purpose? Publication of the Jerusalem Criminal Justice Study Group.

[106] Wheeler, J. A. (1998). Geons, Black Holes, and Quantum Foam: A Life in Physics. Norton, New York.

DEPARTMENT OF STATISTICS

UNIVERSITY OF CALIFORNIA

BERKELEY, CALIFORNIA 94720-3860

E-MAIL: brill@stat.berkeley.edu 